\title{
Losing ¥9 Billion! \\ The Tragedy of Personal Account Crude Oil Product of the Bank of China
}

\author{
Chenfeng $\mathrm{Su}^{1,+}$, Jiaqi Huang ${ }^{2,+}$, Siyue $\mathrm{Ni}^{3,+}$, Yanshan Wang ${ }^{4,+}$ \\ ${ }^{1}$ Wenzhou Yuying International Experimental School, ZheJiang 325014, China, 1808179870@qq.com \\ ${ }^{2}$ Shanghai World Foreign Language Academy, Shanghai 200233, China, 3207624287@qq.com \\ ${ }^{3}$ College of Business, Soochow University, Jiangsu 215006, China, 1771719256@qq.com \\ ${ }^{4}$ College of Business and Public Management, Wenzhou-Kean University, Zhejiang 325060, China, \\ yanshanw@kean.edu \\ + They are all first authors.
}

\begin{abstract}
The price of WTI crude oil futures contract in May dropped to a negative value on April 20, 2020 EST, with the settlement price of -37.63 USD / barrel on that day. The "negative oil price" makes the bank of China's crude oil product customers lose money, leading to risk events. This paper comprehensively combs the context of the crude oil product risk event, including the market background of "negative oil price" and the whole story of the crude oil product risk event. Then the paper concentrates on the reasons why the Bank of China issued such a high-risk products and the rationality of product design, product attributes and product innovation. Who should be responsible for the crude oil product incident is also discussed through the contract analysis. Finally, through the analysis and reflection of the lessons, this paper puts forward the methods and relevant suggestions to improve China's financial management.
\end{abstract}

Keywords: Crude oil product, Negative oil price, Financial risk, Risk management.

\section{INTRODUCTION}

After the spread of Coronavirus, the closing price of the WTI crude oil main contract fell $11.8 \%$ in the last week at the end of February. On the 6th March EST, the OPEC+ negotiations broke down. On 9th March EST, the global stock market was hit by "Black Monday". On 12th March EST and 16th March EST, the U.S. shares were again circuit breaker. Affected by this, WTI crude oil futures main contract fell $15.88 \%$, closing at $\$ 22.89$ per barrel on 18th March EST. Since then, crude oil prices have remained low. On 20th April EST, the settlement price was at $\$ 37.63$ per barrel and the closing price was at $\$ 13.10$ per barrel.

\section{FACTORS OF NEGATIVE OIL PRICE}

The factors of negative oil price are caused by these three aspects: demand-driven, supply-driven, and inventory-driven.

\subsection{Demand-driven factor - the spread of Coronavirus worldwide}

Coronavirus pneumonia has a dual impact on supply and demand through direct uncertainty and has posed a huge damage to the global economy. The coronavirus pneumonia epidemic has become the black swan event that triggered the instability of the global financial market. Because of the rapid spread of Coronavirus, the panic in financial markets has intensified, the price of risky assets has dropped sharply, and market volatility has soared. According to the world economic outlook report released by IMF on 14th April, 2020 EST [1], if the epidemic situation subsides in the second half of 2020, prevention and control measures can be phased out. As policy support measures help economic activities to return to normal, the global economy is expected to grow by $5.8 \%$ in 2021 . Therefore, the coronavirus pneumonia direct consequence to the international crude oil market was affected by the global economic recession and travel restrictions. The global crude oil demand has declined sharply, resulting in the decline of crude oil prices. 
On 15th April EST, the International Energy Agency (IEA) issued an energy market report [2], where the global crude oil demand was expected to reduce by 9.3 million barrels/day in 2020, and crude oil demand was estimated to decline year-on-year by 29 million barrels/day in April and 26 million barrels/day in May. On 16th April EST, OPEC issued the April monthly report on the oil market, which was expected to reduce global crude oil demand by 12 million barrels/day in the second quarter of 2020, while the most serious demand decline would be about 20 million barrels/day in April. [3]

\subsection{The supply-driven factor - the agreed consensus of OPEC}

On the 6th March EST, OPEC+ negotiations broke down. Saudi Arabia announced a price cut and increased production on the 7th March EST, setting off a war on crude oil prices among the world's largest oil-producing countries, which expanded the decline in international oil prices. On 9th March EST, the crude oil future market plummeted after the opening of the market. Tension eased following the OPEC+ meeting on 9th April EST with an agreement to cut output by 10 million barrels per day. However, the agreement came into effect in May and was less robust than the market expected, so the storage was oversupplied. [4]

\subsection{Inventory factor - limitation in store facilities}

Coupled with limitations in storage facilities at American hub Cushing, a deepening bearish market sentiment of oil markets spread. Specifically, panic increased in the futures market as the May contract expiry approached and trader deliberated on how they would take delivery of physical barrels of oil when storage sites are reaching full maximization.

In addition to the reasons for oversupply and short demand, the main reason for the decline of WTI crude oil to negative is the high inventory and the low capacity of storage in Cushing and the difficulties in long-term trading due to local and main pipeline constraints. The rise of inventory and the limit of storage capacity are common problems for the global oil market. However, WTI delivery mode is in the pipeline delivery in the Cushing region, Oklahoma, the midwest of the United States. It is different from the cash delivery rules of Brent crude oil futures contract and the warehouse delivery rules of Shanghai crude oil futures. In the specific delivery process, WTI real-time delivery is characterized by pipeline valve delivery. Several delivery points are designated in the Cushing area, the buyer needs to find the storage tank by itself, and there is no real delivery warehouse in the actual delivery. Therefore, under the background of tight oil storage capacity in the Cushing area, WTI delivery rules were more likely to cause short positions.

As of April 17th EST, the EIA data showed that the inventory of Cushing [6], the place where WTI crude oil was delivered, was 59.74 million barrels, with a storage utilization rate of $78.5 \%$, and the remaining usable capacity of 16.36 million barrels. According to the investigation of consulting agency FGE, the remaining available storage capacity had been reserved, and it was impossible for the buyer to find the delivery warehouse for storage in the Cushing area. As the cost of storage rises, investors who hold long-term futures prefer to roll over or sell futures heavily. So, although selling contracts to buy far-term contracts was facing higher extension costs, most investors moved positions ahead of time before the contract expired. However, on April 20th EST, near the last trading day of the WTI contract in May, some investors still failed to close or move positions by chance. There were still 110,000 positions on the market, about 110million barrels, which even exceeded the maximum storage capacity of 76.1 million barrels in the region. If the long future contract of WTI in May cannot roll over before the contract expired, it must be delivered and received by force. Without the available delivery base, crude oil can only be burned or abandoned locally, and the investors would face huge fines under strict environmental protection law in the U.S., which puts the long-term of WTI crude oil futures in a dilemma. Therefore, investors had no choice but to close their positions without any buyer. Still, instead, the short positions' investors caught the chance by keeping the quotation down through the programmed trading system, and finally the price hit to negative $\$ 37.63$ per barrel, which refreshed the historical record.[5]

\subsection{CME Adjustment on WTI trading rule}

Based on the background of the negative oil price, the change of the trading system in the crude oil futures market deserves attention. In the face of the sharp decline in crude oil prices, the Chicago Futures Exchange (CME) issued a notice on 8th April, 2020 EST, which stated that if the settlement price of WTI crude oil futures in any month dropped to less than $\$ 8$ per barrel, CME clearinghouse would replace the pricing model of all WTI crude oil options contracts and all relevant crude oil options contracts with the Bachelier model on the next trading day. On 15th April EST, CME continued to issue a notice that recent market events increased the possibility that some NYMEX energy futures contracts could be settled at a negative or zero transaction price. Options for these futures contracts might be listed at a negative or zero exercise price; If this happened, all CME trading and clearing systems would continue to function properly. [3]

Therefore, in the crude oil market, the outbreak of Coronavirus and the failure of the OPEC agreement 
resulted in continued pressure on supply and demand fundamentals. Moreover, the sudden pressure on inventory storage and $\mathrm{CME}$ allowing negative oil prices into the futures contract led to the first negative price in the history of the crude oil market.

\section{INVESTIGATION OF LOSSES IN BOC "CRUDE OIL PRODUCTS"}

The crude oil product is the BOC issue linked to individual customers overseas since 2018, crude oil futures trading products, the corresponding datum mark for Eurex Exchange North Sea Brent crude oil futures contract, and New York Mercantile Exchange crude oil futures contract. Individual customers open corresponding comprehensive guarantee accounts, and Bank of China, as a market maker, provides quotations for risk management.[7]Crude oil products are trading products without leverage effect, and contracts are issued on schedule. The contracts are named by combining trading varieties + trading currency + two digits of the year + two digits of the month.

Faced with a sharp drop in crude oil prices, CCB, ICBC, and BCM all successfully extricated themselves. Only BOC cleared the investors at the settlement price of -37.63 US dollars per barrel. By comparing the differences in the product design of these banks, we have the following findings, Table 1 shows:

Table 1. the main differences in the contract designs

\begin{tabular}{|c|c|c|c|c|}
\hline Banks & BOC & CCB & ICBC & BoCom \\
\hline Products & Crude oil products & $\begin{array}{c}\text { Account crude oil } \\
\text { products }\end{array}$ & $\begin{array}{c}\text { Account crude oil } \\
\text { products }\end{array}$ & $\begin{array}{c}\text { Bookkeeping crude } \\
\text { oil products }\end{array}$ \\
\hline $\begin{array}{c}\text { Forced closing } \\
\text { margin }\end{array}$ & $20 \%$ & $50 \%$ & $20 \%$ & April $14^{\text {th }}$ CST \\
\hline $\begin{array}{c}\text { Roll-over date } \\
\text { Estimated } \\
\text { closing cost }\end{array}$ & April $20^{\text {th }}$ CST & April $15^{\text {th }}$ CST & April $15^{\text {th }}$ CST & $\$ 20-\$ 21$ \\
\hline $\begin{array}{c}\text { Estimated roll- } \\
\text { over cost }\end{array}$ & $-\$ 37.63$ & $\$ 20-\$ 21$ & $\$ 20-\$ 21$ & $\$ 6-\$ 7$ \\
\hline
\end{tabular}

\subsection{As for the rolls-over date}

As shown in Table 1, the roll-over date of BOC crude oil product is April 20th EST, later than that of other banks' products, which is the main reason why BOC lost money while others do not. The regulated last trading date of WTI is 3 business day before the 25th EST every month. In 2020, April 25th is Saturday, so 3 business day before is April 21st EST. BOC moved its position on April 20th EST (only 1 day before the last trading date), while CCB and ICBC moved their positions on April 14th EST and April 15th EST, and BCM moved its position on April 13th EST and April 14th EST. BOC set the roll-over date on the 20th EST in order to be closer to the price of crude oil in May. However, there is still a time difference of 3 to 4 hours, which carries a great risk. According to the changes in the positions of WTI contracts in each month, "it can be found that the migration from the near-month contract to the next nearmonth contract has been completed on the 10th-14th EST of each month; after the migration of the original main position is completed, the main contract of the position usually becomes the most actively traded main contract on the 16th-18th of each month." [4] In other words, in the middle and early part of the month, the trading volume is relatively large, while in the second half of the month, the trading volume drops significantly, which is the current market trading pattern. The rollover period should be set in accordance with the market trading pattern, in which the period is the middle and early part of the month, thus bringing the price of the near-month contract closer to the next front-month contract. "In order to hedge the risk exposure of Crude Oil Products, the Bank of China should complet its position move operation in early April when constructing a hedging strategy using WTI crude oil futures to select contracts, rather than being limited by Crude Oil product's design and choosing to move positions on the last two trading days of the WTI 2005 contract."[3] Due to the high cost of storing crude oil and the current global shortage of oil storage space, the closer to the last trading day, the less liquid the futures will be and therefore the risk will be high. Setting the rollover date at 20th EST is a loophole in the design of the contract for BOC crude oil product, and moving the roll-over date relatively early to the middle or the early part of the month would be a much better option.

\subsection{As for the trading time}

The trading time of BOC crude oil products did not precisely match the trading time of the WTI crude oil futures contract in May. The falling of the oil price from 
about $\$ 10$ to a negative number all happened 4.5 hours after crude oil products stopped trading. This pricefalling period is the key to the huge loss of domestic crude oil products. 10:00 p.m. Beijing time on April 20, 2020, is the last trading time of BOC crude oil products. According to the regulations, BOC closed the trading system. At this time, the price of WTI05 contract crude oil of BOC crude oil products fell to about \$10. Although BOC stopped trading, CBOT is still trading crude oil futures. At 2:08 a.m. on April $21 \mathrm{CST}$, it turned negative; at 2:29 a.m. CST, it fell to the lowest price of -40 US dollars/barrel, and the final settlement price of WTI crude oil futures contract on that day was -37.63 US dollars/barrel. On the other hand, the transaction time of the other three banks is more than that stipulated by the Bank of China. Therefore, as for the other three banks, they have more time to respond to emergencies, not to mention the earlier time to move their positions. To sum up, there are some mistakes in the setting of the transaction time of BOC.

\subsection{As for margin and compulsory liquidation}

As shown in Table 1, it is written in the contract signed between the BOC and investors that when the margin is less than $20 \%$, compulsory position closing will be carried out. When asked why BOC did not compulsorily close a position due to huge losses, BOC said that according to the previous agreement and announcement, April 20 is the last trading day of the May contract of crude oil products, and the trading deadline is 22:00 CST. In the early hours of April $21 \mathrm{CST}$, the contract price of WTI crude oil futures in May fell sharply to an unprecedented low price of -40 US dollars. The settlement price announced on the same day was US $\$ 37.63$, the first negative settlement price since the listing of the Chicago Mercantile Exchange Group WTI crude oil futures contract. To eliminate the situation that abnormal reasons such as the system failure of the exchange caused the negative settlement price of the day, BOC actively contacted the Chicago Mercantile Exchange and market participants for confirmation, so the trading of crude oil products linked to the US oil contract was suspended for one day. The announcement of BOC stressed that for crude oil products, long positions will not trigger compulsory position closing when the market price is not negative. For those who have been determined to move positions or offset at maturity, due processing will be completed for customers according to the settlement price, and they will no longer be marked to the market or forced to level. In other words, the crude oil products did not trigger the compulsory position closing during the trading time, while outside the trading time, BOC was unable to deal with the crude oil products, showing that BOC did not consider how to deal with the risks that might occur outside the trading time when designing the crude oil products. On the other hand, the other three banks did not trigger compulsory position closing because the time of position shifting was earlier than that of margin.

\section{RESPONSIBILITY ANALYSIS}

\subsection{Literature review - the responsibility and ethic of financial companies}

Whether a financial company violates responsibility and ethics is hard to define. In general, the basic responsibilities of a company are similar, such as legally registration, legally hiring, accounting management responsibility, contract signing and performance responsibility, legal financing responsibility, protection of consumer rights and interests, and fair competition responsibility. However, the roles and responsibilities of business in society, in particular global business, are being defined more broadly.[8]For example, Corporate social responsibility (CSR) is an intense and increasing interest both in practice and in academic fronts. Investor interest in businesses that engages in CSR activities has grown dramatically. [9]

In the financial market, the financial product adopts the principle of the buyer's responsibility. The manager is responsible for the management and investment of the product, and the remuneration is extracted according to the investment performance. There is no risk-sharing. However, the information asymmetry in the financial market coupled with the limitation of investors' knowledge and ability makes investors often fail to truly understand the risks and benefits when buying investment financial products, and they mainly rely on the recommendation and explanation of product sellers. The purpose of the seller's institution to undertake the obligation of suitability is to ensure that financial consumers can make their own decisions based on the full understanding of the nature and risks of relevant financial products and investment activities and bear the benefits and risks arising therefrom. In this situation, If the seller fails to fulfill the investor's suitability obligation in recommending and selling the fund to the buyer, the seller shall be liable for compensation for the investment loss of the buyer.

However, how to judge whether the sales have the right information to convey the product? As [8]states, "despite the considerable effort in the academic literature to discover a reliable relationship between responsible conduct and financial performance, the evidence remains mixed at best... Where responsibility and wealth conflict, theory and practice may prove difficult to reconcile ..." To date, there has been little empirical research on how traders are managed and the extent to which managerial behavior either fits academic models or complies with regulatory concerns. [11]Meanwhile, ethics have recently become an important issue while ethics and financial investments seem mutually exclusive. [12]According to Boatright's research, the fundamental ethical requirement 
of financial markets is that they should be 'fair'. The most commonly adopted means for ensuring fairness in markets is government regulation, although a significant degree of industry-and firm-level self-regulation is also employed in finance. [13] However, it's sophisticated to estimate if self-regulation of a financial company is in place, and government regulation may exist loopholes and imperfections. Therefore, defining the mistakes of a financial company's responsibilities and ethics is equivocal and complicated.

\subsection{Responsibility Analysis of the BOC}

The Bank of China does need to compensate investors for crude oil products. Through the analysis from different aspects, the Bank of China has defects and deficiencies in this event. The followings are an analysis of various aspects.

First of all, the behavior of the Bank of China didn't follow the contract. According to Article 9 of [14], Party $B$ shall settle the gap or move the position following the method specified by Party A. Suppose Party B is unable to handle normal differential settlement and position shifting transactions due to abnormal market fluctuations on the due date. In that case, it shall be postponed to the next trading day for due date processing. If it is not possible to settle the spread and move the next trading day due to the abnormal market fluctuations, it shall be postponed to the next trading day. Similarly, suppose the margin settlement and position shifting transactions cannot be carried out for five consecutive trading days. In that case, the due settlement price published by Party B shall be applied to the due settlement price. Based on the agreement, If the Bank of China cannot handle normal differential settlement and position shifting due to abnormal market fluctuations on the due date, it shall postpone the deadline accordingly. If it cannot settle the spread and move the position for five consecutive trading days, the settlement price at maturity published by the Bank of China shall be used for the settlement at maturity. Therefore, BOC's settlement price of -37.63 US dollars with financial consumers does not comply with the provisions of the above provisions.

Secondly, the Bank of China does not exercise its management right to force the closing of customers' positions when the market moves in the opposite direction to financial consumers holding positions. According to [15], if the client's trading margin is insufficient and the company of the future fails to notify the client to make additional margin as agreed, the company of the future shall be mainly liable for compensation. The amount of compensation shall not exceed $80 \%$ of the loss resulting from the client's overdraft due to the change of market conditions in the direction of unfavorable position holding. Article 34 provides that if a futures company allows a customer to open a position for overdraft trading, the company of the future shall bear the main liability for compensation for the loss caused by overdraft trading, and the amount of compensation shall not exceed $80 \%$ of the loss. However, in this event, investors are still allowed to continue holding positions in the case of no or insufficient margin for financial consumers. And the Bank of China didn't implement its right of mandatory liquidation, which caused the larger loss. Therefore, the Bank of China bears the main liability for compensation.

Thirdly, the Bank of China failed to fulfill its obligations. According to [16], if the issuer and seller of financial products fail to fulfill the obligation of appropriateness and cause financial consumers to suffer losses in the process of purchasing financial products, financial consumers may request both the issuer of financial products and the seller of financial products to bear the liability of compensation. If financial service providers fail to fulfill their appropriateness obligations and cause financial consumers to suffer losses when they participate in high-risk grade investment activities after receiving financial services, financial consumers may request the financial service providers to assume a compensation liability. However, the Bank of China Limited Financial Market Personal Products Agreement failed to inform that the crude oil product, in addition to the loss of investment principal, may also have a significant impact on the financial situation and life of financial consumers. The bank has not fully revealed the situation of not being able to move the warehouse, nor fully informed the legal consequences of not being able to move the warehouse. Thus, the Bank of China should be liable for the loss of financial consumers.

The Bank of China is indeed supposed to bear the responsibility for its improper behavior. Still, the Bank of China has not held the responsibilities ultimately due to the lack of supervision. Based on the analysis above, the Bank of China needs to take responsibility and provide compensation to investors since the Bank of China failed to follow the contract, protect customers' rights, and fulfill its obligations. However, the Chinese government has not conducted any investigation and sanctions against the bank. The Bank of China's judgment and management of high-risk financial products are not sufficient. It is suggested to further improve the integrated supervision system of the financial market, improve the supervision methods of financial products, strengthen international financial supervision cooperation, and enhance the ability of cross-market supervision.

\section{MORE INVESTIGATION OF EXOTIC FUTURES PRODUCTS}

Chinese central bank (The People's Bank of China) has changed the interest in 2015 to reduce the cost of investment of commercial banks and further encourage investment. PBOC lowered the benchmark interest rate for one-year loans to financial institutions by $25 \mathrm{bp}$ to 
$5.1 \%$, and the benchmark interest rate for one-year deposits by 25 bp to $2.25 \%$, while PBOC also adjust the upper limit of the floating range of deposit rates for financial institutions from 1.3 times to 1.5 times the benchmark deposit rate in conjunction with the promotion of interest rate market reform. [17]

For years, the biggest lenders lived comfortably off household savings, paying deposit rates capped by the People's Bank of China. Smaller regional banks, meanwhile, had to scramble for short-term, unstable, and expensive interbank funding. [18] Due to the decrease in interest rate, the cost of investment of smaller commercial banks decreases, which means that these smaller banks have much powerful competitiveness in the financial market. However, the Bank of China is less sensitive to the fluctuations and policy changes in the financial market due to its rigid bureaucratic system. The Bank of China still lives on the household savings and paying deposit, which the People's Bank of China largely reduced. Thus, their capital for investment actually decreases as policy changes, and their competitiveness in the financial market is also weakened. To attract more retail capital from the market and increase competitiveness among the six biggest commercial banks, the Bank of China began to design and sale financial derivative products to retail investors, further fueled China's wealth management industry, such as the Personal Account Crude Oil product ("crude oil product").

In conclusion, this futures product is basically designed to increase the capital of the Bank of China, further increase their competitiveness, and fix the disparity from other commercial banks, which thrived due to the monetary policy.

\section{CONCLUSION}

To sum up, the event of the large loss of the personal crude oil product of the Bank of China took place because of the negative oil price by decreasing demand of oil, declining of oil supply, and limiting in storage facilities and defect of the bank which include the unprofessional Roll-over date that the Bank of China set, unmatched trading time, and unreasonable rules of margin and compulsory liquidation. According to the analysis above, the Bank of China has responsibility for the large loss, but it didn't be punished because of the lack of supervision. To avoid relative events happened again, both banks and investors need to make progress. The banks should be more sensitive in risk assessment, as well as detecting price and market changes in the financial derivative market on time. Besides, they should make corresponding system adjustments accordingly in the future. Instead of that, banks should improve their risk prevention and control measures. The crude oil product incident was largely due to the automated operations of the Bank of China. This undisciplined trading model needs to be improved. Commercial banks may improve the supervising system by adding supervisors for price fluctuations in financial derivatives outside of trading hours or improve systems for automated trading. For the investors, they should understand the risks of trading thoroughly in advance of trading. Many financial derivatives trading models, while appearing simple and easy to understand on the surface, are very complex in terms of internal relationships and have extremely high potential risks. [19] Traders should be careful not to be blinded by the immediate benefits until they have a thorough understanding of the trading patterns of financial derivatives. Being a good observer and careful analyst is the only way to reduce risks and safeguard their belongings in the trading market.

\section{REFERENCES}

[1].International Monetary Fund. (2020). World economic outlook. Retrieved from: https: / /www. imf.org/zh/publications/weo/Issues/2020 /04 /14 /weo-april-2020

[2].Oil Market Report. (2020). Oil Market Report April 2020. Retrieved from:https://www.iea.org/reports/oil-market-reportapril-2020.

[3].Bu, H., Lu, F., \&Wei, Y. (2020). Who is the fault of "crude oil product" Lessons and Reflections on product innovation of China's commercial banks. No15(6). 309.

[4].Wang, N. (2020). WTI05 contract and BOC crude oil reflection and Enlightenment of risk events. No34(5).18-19.

[5].Zhang, J., \&Wang, P. (2020). Analysis of the deep reasons for the formation of negative price of WTI. No28(6).60-61.

[6].On Some Issues Concerning the Trial of Futures Dispute Cases. U.S. Energy Information Administration. (2021). Retrieved from: https://www.eia.gov /dnav/pet/hist/LeafHandler.ashx?n=PET\&s=W_EP C0_SAX_YCUOK_MBBL\&f=W.

[7].Yang, H. (2020). Reflection on legal supervision of high-risk business of commercial bank-From the perspective of the Crude Oil Treasure incident of the Bank of China. No108(5). 82-88.

[8].Warhurst, A. (2005). Future roles of business in society: the expanding boundaries of corporate responsibility and a compelling case for partnership. Futures, 37(2-3), 151-168. Retrieved from: https://www.sciencedirect.com/science/article/pii/ S0016328704000850. 
[9].Hassan, A., \& Harahap, S. S. (2010). Exploring corporate social responsibility disclosure: the case of Islamic banks. International Journal of Islamic and Middle Eastern Finance and Management. Retrieved from: https://www.emerald.com/ insight/content/doi/10.1108/17538391011072417/f $\mathrm{ull} / \mathrm{html}$.

[10].Windsor, D. (2001). The future of corporate social responsibility. The international journal of organizational analysis. Retrieved from: https://www.emerald.com/insight/content/doi / 10.1108/eb028934/full/html.

[11].Willman, P., Fenton-O'Creevy, M., Nicholson, N., \& Soane, E. (2002). Traders, managers and

loss aversion in investment banking: a field study. Accounting, organizations and society, 27(1-2), 8598. Retrieved from: https://www.sciencedirect.com/science/article/pii/ S0361368201000290

[12].Elmelki, A., \& Ben Arab, M. (2009). Ethical investment and the social responsibilities of the Islamic banks. International Business Research, 2(2), 123-130.

[13].Boatright, J. R. (2010). Ethics in finance. Finance ethics: Critical issues in theory and practice, 3-19. Retrieved from: https://onlinelibrary.wiley.com/doi/book/10. 1002/9781118266298\#page $=9$.

[14].The Bank of China. (n.d.). the Bank of China Limited Financial Market Personal Products Agreement.

[15].The Supreme People's Court of China. (2003). the Provisions of the Supreme People's Court Cai, F. (2020). Russia's "OPEC" policy: from active participation to negative response.No9(3).152.

[16].Civil Administration Professional Committee of the Judicial Committee of the Supreme People's Court of China. (2019). The Minutes of the Meeting on Civil and Commercial Adjudication of National Courts.

[17].Monetary Policy Department of the People's Bank of China. (2015). The People's Bank of China (PBOC) has decided to lower the benchmark interest rates on RMB loans and deposits for financial institutions and widen the floating range of deposit rates. Retrieved from: http://www.pbc.gov.cn/zhengcehuobisi/125207/125 213/125440/125835/2812382/ index.html.

[18].Ren, S. (2020). What Opening Up a Bank Account Taught Me About Oil Futures. Retrieved from: https://www.bloombergquint.com/global- economics/bank-of-china-s-oil-futures-blowupcomes-down-to-bureaucracy.

[19]. Li, J. (2020). "Crude Oil Product" burst to ring the alarm of China's financial innovation risk. Retrieved from: https://www.fx361.com/page/2020/0826/6977695.s html. 